\title{
Erratum to combination MET- and EGFR-directed therapy in MET- overexpressing non-small cell lung cancers: time to move on to better biomarkers?
}

doi: $10.21037 /$ tlcr.2017.08.07

View this article at: http://dx.doi.org/10.21037/tlcr.2017.08.07

Erratum to: Transl Lung Cancer Res 2017;6:393-395

In the June 2017 issue of Translational Lung Cancer Research (TLCR), the editorial article "Combination MET- and EGFRdirected therapy in MET-overexpressing non-small cell lung cancers: time to move on to better biomarkers?" (1) was published with some errors. The affiliation of Section Editor Viola Zhu in the provenance part is wrong. The correct affiliation is University of California, Irvine School of Medicine, Orange, CA, USA.

The publisher regrets the error.

\section{References}

1. Santini FC, Kunte S, Drilon A. Combination MET- and EGFR-directed therapy in MET-overexpressing non-small cell lung cancers: time to move on to better biomarkers? Transl Lung Cancer Res 2017;6:393-5.

Cite this article as: Erratum to combination MET- and EGFR-directed therapy in MET-overexpressing non-small cell lung cancers: time to move on to better biomarkers? Transl Lung Cancer Res 2017;6(5):611. doi: 10.21037/tlcr.2017.08.07 